\title{
The Application of Yi Nationality Costume Culture in Panzhihua Tourism Industry
}

\author{
Lixia Wang \\ Art College \\ Panzhihua University \\ Panzhihua, Sichuan, China 617000
}

\author{
Mengmeng Zhao \\ Fashion College \\ Shanghai University of Engineering Science \\ Shanghai, China 201620
}

\begin{abstract}
With the supply side structural reform, Pan-xi city is in the transition from heavy industry city to a tourist city, and that leads to the development of the tourism industry. On this background, the article mainly discussed the application of $\mathrm{Yi}$ nationality costume culture in Panzhihua tourism industry from the perspective of textile souvenirs.
\end{abstract}

Keywords-Yi nationality costume culture; tourism industry; tourism souvenirs

\section{INTRODUCTION}

In order to give the tourists a totally new experience, tourism industries always try to develop the local resources and cultural characteristics, which can give the tourists a distinctive impression. There is no exception all over the world. Sichuan Panzhihua, as an emerging tourist city in China, has a question to answer, that is how to use the local national resources and features in its own tourism industry.

This paper will take the costume culture of Yi nationality in pan-xi as an example, discuss the application in tourism, and make some suggestions on it.

\section{PAN-XI TOURISM IN THE URBAN TRANSFORMATION}

Pan-xi is the combination of Panzhihua and Xichang, the cities in the south of Sichuan province. In the past, Panzhihua was a heavy industry city with the pillar industry - steel smelting, a national "three line construction" of the product, and a typical resource-based city. It was one of the ten most-polluted cities in china ten years ago. But today, all has changed. In the wave of ecological civilization construction, Panzhihua has completed the transformation and become "sunshine city", "Kang Yang resort". Panzhihua adheres to take the ecological advantages of the natural resource to the extreme with the health industry as a breakthrough in the transformation of the city. In order to promote the supply side structural reform, increase marketing efforts, especially in the field of tourism consumption in Panzhihua tourism consumption, on June 1th, 2016, the Municipal Tourism Bureau held Panzhihua tourism product marketing forum, focusing on product integration, marketing and marketing products issued by the time, range and standard administration of the products. 18 tourism enterprises participated in the meeting, including Sichuan xinguolv, Hongge hot springs hotel, Xin Island Amusement Park, Gesala scenic spots and 26 degree orchard.

\section{The COSTUME CUlture OF Yi NATIONALITY}

Panzhihua is a multi-ethnic region. There are a total of 42 minority nationalities and the population of 139,300 people. The ethnic groups including $\mathrm{Yi}$, which accounted for $8.9 \%$, Lisu, Miao, Naxi, Bai, Dai and manchu. Yi is one of the ancient nationalities of China. In the long history, the Yi people created a splendid human culture. For the Yi people, bright and colorful ethnic costumes are not only the material wealth, but also the crystallization of the wisdom of the people. DaLiangshan and Xiaoliangshan Mountain are important settlements for Yi people. Before the democratic reform in 1954, the region was in the stage of slavery, and the social development was very slow. So Liangshan dress retains more inherent cultural traditions and is the most representative of the Yi clothing.

The Yi People's clothing image pattern takes shape rather than the pursuit of realism. They take the shape of natural objects as the basic elements of modeling to grasp the shape trend. Sometimes they reproduce the whole picture, sometimes record parts, sometimes create variants, sometimes paint realistically and the tendency is more obvious. Decorative patterns are abstracted, but it is not difficult to identify the shape in its infancy [1].

There are five colors for Yi dress. The white or blue stands for sky, red stands for fire, yellow stands for people, black stands for ground, and green stands for forest. These five kinds of color constitute the main color of Yi People's dress. The first suit usually is black. Blue is the basic color while the decorative pattern is usually red, yellow or blue. The transition color is rarely used except green. The costume carefully arranged are colorful and harmonious with a unique style of beauty.

\section{RESEARCH AND DESIGN OF TEXTILE SOUVENIRS}

In China tourism market, from Xinjiang to Yunnan, from jiangnan to the Central Plains, tourism textile product is a special category in the textile design with the tourism economy upsurge. The textile souvenirs not only have the characteristics of textile materials and technology, but also has the distinctive features of the humanities of tourism area. 
It is a collection of commemorative, collection, functionality, and many other integrated product design [2].

Costumes of ethnic minorities in China are bright, distinctive, colorful and exquisite beyond compare. It is an important part of the excellent history and culture of all ethnic groups. Clothing production maintains a distinctive national and regional characteristics from raw materials, textile technology, style, to decoration. It is obvious that the development of the national costume has a unique advantage for the local economy. In China there are different textile souvenirs design with local cultural characteristics in different regions. Some cities provide a successful reference model for the design of tourism textile products, such as the cloth tiger in Shandong, Zodiac Pendant in Xi'an , tie-dyed in Yunnan, blueprint cloth in Jiangnan, Miao batik, Mosuo hand woven, silk in Suzhou, Tibetan Pulu, famous embroidery around the country etc [3]. These products, based on the local traditional dress culture and the original handmade charm, become the most attractive tourism souvenirs. They play a role in promoting regional culture as a local business card.

\section{Some Suggestions on ETHNic Costume DEVELOPMENT IN PANZHIHUA}

According to the above ideas, Panzhihua can develop textile souvenirs with local characteristics using the Yi dress culture to enrich the rich tourism market. In general, we can divide the products into the following two categories:

Clothing and accessories category, mainly refers to those apparel or textile products with the characteristics of tourism area, that are suitable for tourists to wear and use, including T-shirts, scarves, bags, hats, hair ornaments etc.. These products are generally cheaper, but also easy to carry, so it is often the first choice of tourism souvenirs. This type of product must have strong personalized color, diverse selection of materials, four seasons applicability, light portability and fashion. Fashion elements combine with national characteristics, that will make it difficult for consumers to resist.

Handicraft, mainly refers to the textile products with the characteristics of tourism, suitable for tourists to carry, used for indoor decoration and application, such as home furnishing supplies, hanging, decorative painting, letter holder, cushions, toys, ornaments, all kinds of ornaments, etc. On the one hand, we should inherit the traditional handicraft products with strong regional and national characteristics, with the most pure traditional culture and the charm of the hand. On the other hand, we need to innovate and create new products with the traditional characteristics of the nation that the market demand according to the development of the times. This kind of new product inherit the traditional modeling and technology, combined with the needs of times. We should vigorously develop new varieties and themes with the characteristics, expand the space for traditional handicrafts and tourism souvenirs. We should actively develop tourism souvenirs market by looking for business opportunities with inheritance and innovation [4].

\section{The PROMOtion Mode OF NATIONAL Costume IN PANZHIHUA AREA}

The development of Panzhihua's tourism industry like a raging fire, the project of tourist souvenirs promotion is also increasing. Compared to other regions the promotion mode of textile and apparel souvenirs is slightly weak, but there are also many new attempts

\section{A. Co-construction Model between College and City}

In recent years, Panzhihua University actively carries out school cooperation combined with local economic development. In 2013Panzhihua University signed a strategic cooperation framework agreement with Yanbian county government, in 2014 with the western government, and in 2015with Dechang County People's government. The Art Institute combined the graduation design topic and the local demand combination and carried on the extremely regional characteristic dress design. For three years, the Academy of Arts in Panzhihua organized a cooperative project outstanding graduate design exhibition. The content relates to clothing, embroidery, tapestry etc.. That provides a good exploration for the practical application of the promotion of national costume.

\section{B. Promotion of Souvenirs in Tourist Attractions}

The demand of the tourist attractions on the clothing culture products can be divided into two categories. One kind is the demand of soft outfit based on the folk culture of tourism and the transformation of urban rural landscape. The hotel's image decoration design is an important aspect, including the hotel interior soft outfit and the service personnel's clothing and so on. The second category is clothing and peripheral products with the memory of tourism sold in the attractions. The products are mainly ethnic costumes, with local cultural characteristics, such as clothing, bags, wall hangings, scarf, accessories etc.

\section{Promotion Rely on Youth Project of Career Creation}

Panzhihua government strongly supports the entrepreneurship of young students as the country advocates that all over the world should pay attention to Youth Innovation and Entrepreneurship. Students and other young people carry out the research, development and sales promotion on tourism textile souvenirs with Pan-xi characteristics in different forms. Some of them set up personal studios to supply custom-made gift. Some of them set up a studio to teach local crafts and inherit the arts. Some of them set up a counter or physical store in the mall to carry out the national style of clothing accessories and home textile sales. Some of them use the form of online shop to sale products designed by themselves. They also actively participate in a variety of innovation and entrepreneurship competition to enhance the visibility.

\section{CONCLUSION}

In recent years, Panzhihua has done lots of work in the development of rehabilitation and tourism, and has made some achievements, but it is far from the formation of pillar 
industries. We should combine the characteristics of nationality and locality with the modern fashion idea. We should work hard in the creative and quality to design products that have both natural and humanistic properties. At the same time we need to strengthen the innovation of marketing channels and methods and do a favor to the transformation of Panzhihua.

\section{REFERENCES}

[1] Ma Yanyang; survey and analysis of Liangshan tourism souvenir market [J]. management observation.

[2] Xiao Dongqiong; national costume design and tourism development and promotiont - a case of Guangxi folk tourism development [J] "Beauty and Age (I)" in 201503.

[3] Wei Liying, Development rule and development trend of tourism souvenirs in China [J]. Journal of Guilin Institute of Tourism, 2006 (12): $727-728$.

[4] Shuai Ligong, tourist souvenirs design [M]. higher education press, 2007. 